brought to a state of paradise appropriate to Christ's return. To some this will sound quaint. But the fact remains that a science-based utopia, with its supreme confidence in the technological fix, had at least some roots in a newly conceived religious imperative: to hasten the millennium.

It is therefore possible to argue, as Ruse does, that the struggle between evolution and creation is a contest between rival versions of millenarian theology. The world-view and conservative moral values of the creationists tend to be informed by a theology in which God alone can instigate a more perfect society through human redemption. The world-view of the popularizers of evolutionary biology tends to be informed by the legacy of an alternative reading in which humans had to take responsibility for shaping the future. Not for nothing did Julian Huxley describe his evolutionary humanism as a "religion without revelation".

Ruse knows that not all of Darwin's disciples can be shoehorned into his scheme. Indeed, he takes trouble to discuss exceptions. The late Stephen J. Gould is an obvious one, given his aversion to progressive readings of the fossil record and his equally adamant line in Rocks of Ages (Ballantine, 1999) that the respective magisteria of science and religion must not be allowed to overlap. For Ruse, Gould is the exception that proves the rule - not least because, on closer analysis, his reduction of religious provenance to questions of morality places him squarely in the secularizing tradition. And one might add that a close analysis of Gould's controversy with Simon Conway Morris shows that his well-known take on the fossils of the Burgess shale was, by his own admission, informed by his own social values.

This book is aimed at a general audience. Ruse's style is chatty and informal, sometimes incongruously so. His historical treatment of Christianity will be too sketchy for fastidious scholars. But let us not underestimate the importance of his message. His appeal is to all who love science; his exhortation is that we "must do more than simply restate our positions or criticize the opposition". A prerequisite of progress in this cultural struggle is that we should recognize the metaphysical assumptions underlying dogmatic forms of scientific naturalism, and be willing to investigate the concerns that motivate criticism.

Ruse has done his best to reveal both. $\mathrm{He}$ dedines to be a prophet of doom, but precisely because creationism is linked in America with perceived moral and political threats impinging on society, he cannot see it vanishing any time soon. Insofar as he has a remedy, it is that Christian and secular evolutionists should not waste time sniping at each other but collaborate instead. In this regard he would be pleased to learn that Richard Harries, the bishop of Oxford, has joined the evolutionist Richard Dawkins in alerting the British public to defects in creationist rhetoric (unlike an unhappy predecessor, Samuel Wilberforce, who in 1860 tried to outwit Huxley). In a joint article published in The Times on 10 June 2005, the two Richards gave complementary reasons why the promotion of creationism in schools should be resisted.

John Hedley Brooke is at Harris Manchester

College, University of Oxford, Oxford OX13TD, UK.

\title{
The rise of the computer
}

\author{
Electronic Brains: Stories from the Dawn of \\ the Computer Age \\ by Mike Hally
}

Granta: 2005. 224 pp. $£ 15.99$

Published in the United States as In a Fraction of a Second by Joseph Henry Press (\$27.95)

\section{Anthony Ralston}

Writing a history of events that took place 50 years ago has the advantages that almost all the documentation is available, and that some of the protagonists are alive to be interviewed. Mike Hally has done this for his book about the development of computers in the years just after the Second World War. But the danger of relying too heavily on such interviews is that important topics can be missed if there are no surviving protagonists.

Electronic Brains grew out of four 15-minute programmes that Hally wrote and produced for $\mathrm{BBC}$ radio in 2001. As he accumulated far too much material for one hour of broadcasting, this volume contains much more information than the radio series.

When writing about computers, the question arises as to what you mean by 'computer'. Most people today would agree that this word implies a machine that is general purpose (it can be programmed to solve essentially any solvable problem), electronic, has a stored program that is held and executed in the machine, and digital, being based on discrete rather than continuous technology. Even so, it is perfectly reasonable to discuss, as Hally does, the pre-history of modern computers, when they were often special-purpose, sometimes mechanical, and seldom

IMAGE
UNAVAILABLE
FOR COPYRIGHT
REASONS

Big deal:UNIVAC was among the first stored-program computers. stored-program. It is nevertheless surprising to find a chapter devoted to MONIAC (Monetary National Income Automatic Computer), an analogue, special-purpose, hydraulic, externally programmed device built in England for economicmodelling. But the chapter is fascinating, and I hurried over to the Science Museum in London to view its MONIAC exhibit.

The chapters on some very early computers, UNIVAC (Universal Automatic Computer, Eckert-Mauchly Computer Corporation, USA, 1951), EDSAC (Electronic Delay Storage Automatic Calculator, University of Cambridge,
1949), and LEO (Lyons Electronic Office, an adaptation of EDSAC for business applications, 1951), are competent expositions about three of the first computers to satisfy the definition in the previous paragraph. This material will be familiar to most computer scientists but not to laypeople, who will find much of interest about the development of these computers and the people who developed them.

The chapter on the RAND 409, a computer built by Remington Rand of Rowayton, Connecticut, is another matter. I admit to prior ignorance of this computer, but the startling thing about this fascinating chapter is that neither here nor in the later chapter on IBM is there any mention of the IBM Card Programmed Calculator (CPC). The CPC was contemporary with, and similar to, the 409 , sold better, and was much more influential in the later development of computers. The CPC rates a full page in the 1996 book Computer: $A$ History of the Information Machine by Martin Campbell-Kelly and William Aspray (Basic Books), whereas the 409 is not mentioned at all. Hally's book also contains chapters on the pre-history of computers in the 1930 s and $1940 \mathrm{~s}$, as well as on early computers in the Soviet Union and Australia.

The final chapter, on the rise and dominance of IBM, is most noteworthy for the remarkable daim that IBM "doesn't figure much" in the early history of computers, "at least until the mid-1960s". Actually, as Hally later makes dear, by the early 1950 s IBM was already abreast of its only real competitor, Remington Rand, which bought the Eckert-Mauchly firm in 1950 . By the late 1950s, IBM was already in a class by itself.

Hally is quite accurate about hardware but, perhaps because he is an engineer, less so about software. One blooper: the American journal Mathematical Tables and Other Aids to Computation, published by the National Research Council in the 1940 s and 1950 s, is referred to as a "Russian journal". Still, this book contains enough fascinating material to be of interest to both computer experts and non-experts. Anthony Ralstonis professor emeritus at the State University of New York at Buffalo. His mailing address is Flat 4,58 Prince Consort Road, LondonSW7 2BE, UK. 